\title{
Art and money: Three aesthetic strategies in an age of financialisation
}

\author{
Max Haiven \\ Nova Scotia College of Art and Design, Canada
}

\begin{abstract}
Recent decades of financialisation have seen a significant growth in art that mobilises various forms of money as artistic media. These range from the integration of material money (coins, bills, credit cards) into aesthetic processes, such as sculpture, painting, performance, and so on, to a preoccupation with more ephemeral thematics including debt, economics, and the dynamics of the art market. This article explores three (and a half) strategies that artists use to engage with money: crass opportunism; a stark revelation of money's power; a coy play with art's subjugation to money; and a more profound attempt to reveal the shared labour at the heart of both money and art's aesthetic-political power. Money's perennial appeal to artists stems from the irony of its tantalising capacity to almost represent capitalist totality. At their core, both money and art are animated by a certain creative labour, a suspension of disbelief, and a politics of representation. Artistic practices that use money can provide critical resources for studying, understanding, and seeing beyond the rule of speculative capital.
\end{abstract}

\section{Keywords}

Money, art, representation, mediation, aesthetic strategy, financialisation

\section{The crises of representation under capitalist totality}

In the introduction to his recent book Representing Capital, Frederic Jameson (2011) sums up a theme that has run throughout his career as a prominent Marxist cultural critic: the fact that capital - that massive force in our world, that inhuman intelligence or agency at the core of the capitalist economy - both demands and refuses to be represented. His book, which is a new reading of the first volume of Marx's Das Kapital, focuses on how that famous text is at once the most robust attempt to represent capital through language, and also, ultimately, a beautifully failed project. Drawing on the insights of György Lukács, Jameson explains that this is because, in contrast to the hypotheses of mainstream economists (and even many Marxists), capitalism is not simply an economic system whose power is limited to the ebb and

\section{Corresponding author:}

Max Haiven, Nova Scotia College of Art and Design, 5163 Duke Street, Halifax, NS B3J 3J6, Canada.

Email: maxhaiven@gmail.com 
flow of commodities and the exploitation of labour. Rather, capitalism is a totality: its economic components rely, ultimately, on political choices; these political choices in turn rely on a set of cultural meanings; these cultural meanings in turn rely on aesthetic conventions; and these conventions in turn rely on economic fundamentals (see also Jameson 1981; 1991). Or, if you prefer, the social, cultural, economic, political, aesthetic, and ideological components of capitalism all fit together in non-linear and non-causal ways. In contrast to the economic reductionism that has long plagued Marxist cultural critique, Jameson wants us to develop an understanding of capitalism that sees all these dimensions as interconnected and interreliant, like a proverbial house of cards.

In this sense, capitalism is a form of power that is intimately stitched into the fabric of everyday life and that animates and is animated by a host of social institutions (in the broadest sense of the term), from investment banks to the convention of heterosexual monogamy, from the aesthetics of postmodern pastiche to the structures of representative democracy. A notion of capitalist totality does not mean that resistance is futile, or that all individuals and all social structures automatically and uncritically obey the grim dictates of capital in every case. Rather, it means that each and every social, aesthetic, political, cultural, or economic process must be unpacked and understood dialectically. That is, we must approach everything as a site of power and contestation, capture and flight, difference and repetition, utopianism and dystopianism, price and value. Yet unlike a cheapened Foucauldianism, with its blithe celebration of 'resistance' for its own sake (see Haiven, 2014: 155-76), such an approach insists that we recall the way in which all these forms of power are unified or contextualised within the most remarkable, unique, and - in light of the current ecological catastrophe - dangerous form of social organisation in human history. By the same token, recalling capitalist totality also reminds us that this whole paradigm is the product of a perverse and almost unrecognisable form of human cooperation, and that, as a result and in spite of all its power, it is open to radical and revolutionary transformation.

Such an approach to capitalist totality also means, for Jameson, an understanding of the so-called crisis of representation - a term familiar in many disciplines. It pervades, for instance, the post-modern aesthetic scene, animated as it is by a distrust of modernist, Romantic and Enlightenment representational strategies, from realism to surrealism to socialist realism. Such a crisis has delivered us over to an artistic moment more than ever dedicated to endless introspection, deconstruction, cynicism, irony, and a concern with process, where the objective of art is no longer to represent the world but to (often ostentatiously) call into question the very desire to represent in the first place (see Anderson, 1998; Harvey, 1990; Jameson, 1991).

This crisis of representation, tied as it is to the rise of postmodernity (or 'late capitalism') is familiar in other fields as well. For instance, political studies have, for years, been struggling with the question of how to justify the claims of so-called representative governments, especially in an age of globalisation. This is an age when multiculturalism is a (sometimes difficult) fact of life, when indigenous nations around the world are making their rightful claims against colonial-settler states, and when human migration has become commonplace and more liquid than ever. More profoundly, it is an age when the seemingly borderless force of transnational capitalism wreaks utter havoc on economies and societies around the world with impunity, and often with government complicity. Who the state represents and how that representation ought to be imagined are burning questions in an age of crisis.

So too might we point to a crisis of representation in the realm of economics, one brought so horrifically home to roost in 2008 when trillions of dollars worth of equity seemingly disappeared into the æther over a matter of days. This was, in effect, a double crisis of 
representation. First, it was a crisis for the hegemonic discipline of neoclassical economics that was ultimately forced to concede that its quasi-scientific measures and formulae for representing global wealth and its movements had failed in their task. Economics was revealed to be what Pierre Bourdieu (2005) always told us it was: a particularly powerful, if deeply problematic, form of social theory. In other words, an almost vanguardist form of socioeconomic praxis which, through its representational paradigm, managed to merge the vast majority of mainstream political interests (whether allegedly free-market or allegedly socialist) into a 'historic bloc' based on the fundamental belief that the relationship between material realities and neoclassical economics' representation of those realities was almost perfectly mimetic.

Second, the 2008 financial crisis was also a moment when the main financial instruments of the global economy showed their all-too-human character. Critics such as Donald Mackenzie (2006) have argued that financial models operated as 'performative' structures: they do not simply represent objective financial realities, they bring those realities into being in ways reminiscent of Foucault's (1979) exploration of the way regimes of truth, rather than describing objective realities, brought new orders of power and knowledge into being. Christian Marazzi (2008; 2010), though he avoids Mackenzie's terminology, has likened the play of financial markets to a linguistic game, though one intimately connected to the struggle over language, power, and labour germane to the contemporary politics of cognitive capitalism. Likewise, Marazzi's close associate Franco 'Bifo' Berardi (2012) has characterised the imaginative acrobatics of the financial sphere as a form of perverse poetry (see also Haiven, 2014: 15-42).

Beyond the financial sector's depraved antics, this crisis of representation in the global economy at large has dramatic and sorrowful impacts. It is borne out, for instance, in the startling fact that a large percentage of the world's farmers are malnourished thanks to the way global financialised capitalism undervalues their labour, gambles with global crop prices, and drives corporate bio-piracy (Patel, 2007). It is also played out in the ironies of austerity, where somehow countries that were rich yesterday are poor today, though the nuts and bolts of their economies have not substantively changed (see LiPuma and Lee, 2004).

All of these crises of representation arise from a profound disconnection between the price of things and their actual value. That is, there is some fundamental and terrifying chasm between, on the one hand, the quantity and qualities of money in a globalised age and, on the other, all those things that, today, increasingly, money seems to unduly influence: the value of food, the value of art, the value of human life, the value of culture, the value of land, the value of the public sphere, indeed, the value of the climate itself. Money seems to measure or represent everything today, or, more accurately, mis-measure and misrepresent everything.

But as Leigh Clair La Berge (2013) reminds us, it is all too easy to castigate today's postmodern financial regimes for their abstractions of value and forget that such processes of abstraction have always been at work under capitalism. It is all too easy to decry 'Wall Street' based on an ahistorical and politically questionable nostalgia for 'Main Street'. Here Marx is instructive. It is notable that, even in spite of the fact that he himself bore witness to many financial panics and crises, Marx spent relatively little time analysing them, instead insisting that a firm understanding of the abstraction of value at the level of labour exploitation was of primary concern (see Harvey, 2006).

For Marx, all prices, even those in the most seemingly straightforward economic transactions, are skewed representations of 'real' value. Value is ultimately the productive capacity of labour that, through the process of capitalist exploitation, becomes encrypted in the commodity (see Nelson, 1999). Yet the price at which the commodity circulates is always 
already an inaccurate measure of the value inherent to it for two reasons. The first, and most concrete, is that commodities circulate within a capitalist economy that is fundamentally skewed and distorted by inter-capitalist competition, the presence of non-capitalist or paracapitalist forms of exploitation within capitalism (colonialism, slavery, etc.), and the economic chaos of financial markets, rent, and countless other factors (Harvey, 2006). So the price of, say, a loaf of bread, is never quite 'equal' to the quantity of labour power invested in its production.

The second reason is more complicated. Price is a measure of value denominated in money, yet money is also the means by which the producer of value (labour) is disciplined. There is therefore an inherent contradiction between money's multiple roles under capital. It must, at once, be the medium of exchange, the measurement of value, the standard of deferred payments, and the store of value, as per the standard, non-Marxian definition of money's four essential functions. But within a Marxian framework, money must both represent value and discipline the production of that value. That is, money must at the same time be a credible and useful way of manipulating the world's wealth (labour power, solidified into commodities) and be the weapon used (most of the time at least) to extort that wealth from the working classes (Caffentzis, 2013). It is this contradiction that leads to all manner of difficulties, and to the centrality of struggles around wages within capitalism. As much as these struggles are about the material matter of how much workers will be remunerated, they are also attempts to (partially) liberate workers from the discipline of money. Within capitalist economics, this leads to a whole array of contradictions that can manifest themselves as familiar crises: the crisis of the falling rate of profit, of overproduction (or underconsumption), and so on (see Lapavistas, 1999).

The nuances of this system are too complicated and hotly debated to entertain here; I merely wish to signal that money under capitalism is both necessary and in constant crisis, a crisis borne from the fundamental fact that money is supposed to represent value, yet never quite does. Within this framework, we can understand neoliberalism as the increasing subordination of all spheres of value to monetary price. Privatisation and the neoliberal turn in public management represent the application of market discipline and measurement to a whole new spheres of previously uncommodified activity. Neoliberalism sees a certain free market fundamentalism enter all arenas of life, which holds that the most universal, fair and reliable measure of value is price (McMurtry, 2002). Hence 'economies' of value - like education, art, love and charity - which once (problematically) enjoyed some limited autonomy from direct market influence - now seem everywhere increasingly dominated by economic imperatives.

Of course, the worry that money has somehow overstepped its bounds and become too powerful is ancient and ubiquitous. Practically everyone today would agree, from anarchocommunists to Christian fundamentalists. But here I agree with Jameson (2011: 45-47): blaming money itself is wrongheaded. It's not that money is or should be a neutral tool, as per the illusion of bourgeois economists (Caffentzis, 1989). Rather, money is just one element, though a uniquely important one, of capitalist totality. As Jameson reminds us, Marx himself was quite hostile to critics of his day who sought to reform the system through legislative changes to the monetary system, or who sought to 'correct' capitalism's imbalances and excesses by inventing new currencies (see North, 2007). Rather, as Anitra Nelson (1999) shows, Marx saw money as a key manifestation of capitalism - a system where power is, ultimately, based not on who has the most money, but on who controls the means of production. Money facilitates this system by disciplining us all, collectively and individually, and compelling us to reproduce capital. The ruling class uses money to buy labour time. And lack 
of money, or the fear of lack of money, is the invisible whip that is held over all our heads, and also the heads of governments large and small, to ensure we all fall in line. For Jameson (2011), money is a form of mediation - a necessary but flawed component of a larger system.

Money is, of course, largely worthless: today it takes the form of token-like coins with no intrinsic metallic value, of printed slips of paper, or, increasingly, of some mass immaterial hallucination of credit and debt, held somewhere in a vast global computer network, haunting our lives like some digital panoptic superego, always watching. So for Marx and Jameson, money is not the root of all evil, but it nevertheless faciliates the evil of a system that fundamentally values accumulation over human life and happiness.

But for Jameson capitalist totality is also driven by a fundamental paradox: it is inherently unrepresentable, yet it demands representation. The world in which we live is made up of far too many moving, interconnected, inter-reliant parts to be fathomable to any single imagination. The sublime interdependency of the system, one that incorporates each of us, all art, all science, all politics, exceeds our ability to create what he calls 'cognitive maps' of our social world (Jameson, 1990). As such, any cultural text (and, for that matter, any economic formula, theoretical excursus or visual representation) will always be an incomplete, partial, and flawed representation of the world: a mediation.

\section{The financialisation of art in the era of ætherwork}

It is on this note that I want to turn to the question of art and money and, in particular, works which use coins, bills, credit cards, or representations thereof as artistic material: money-art, for short. A few initial observations might be made about this practice. The first is that it is an aesthetic growth area. Early pioneers in the exploration of money as an artistic medium include Marchel Duchamp, and a group of turn-of-the century American tromp l'œil painters including William Michael Harnett, John Haberle, John Frederick Peto, Otis Kaye, and Victor Dubreuil (see Shell, 1994). In the decades following the Second World War, experiments by Joseph Beuys, Andy Warhol, Cildo Meireles, Akasegawa Genpei, Chris Burden and, most famously, J.S.G. Boggs helped expand the field (see Siegel and Mattick, 2004; Weschler, 1999). But since the mid-1980s we have witnessed a massive global explosion of artists working with money-art. The other initial observation is that much of this more recent work is atrociously bad: conceptually lazy, aesthetically immature, and politically tepid.

On the level of symptomatology we can understand the enthusiasm for working with money as a medium as a relatively direct response to the post-Cold War globalisation of financialised neoliberal capitalism including, on the one hand, a vast geographical expansion of monetary flows and, on the other, an ever more intensive imbrication of money in institutions, everyday life, and the play of subjectivity. But I also want to suggest that this work with and on money is something of a desperate attempt (sometimes conscious, sometimes unconscious) to grapple with the magnitude of a capitalist totality increasingly coordinated by money. Money is, despite all its flaws and its inherent inability to represent 'real' underlying value, an almost mesmerising cypher for the capitalist totality that it helps coordinate and facilitate. My hypothesis is that artists' fascination with money stems from the strange way it expresses the central contradiction outlined at the beginning of this article: capitalist totality at once calls for representation and refuses to be represented. Beyond the more self-evident meanings and gestures of any particular artist or work in this field, I believe this contradiction preoccupies the inspiration, the strategy, and the reception of money-art.

I want to identify three strategies I see at work in money-art. Well, really three and a half 
strategies. The first is not really a strategy at all: it is just rank opportunism. Given that, today, the financialised ruling class is defined largely by their access to money, many so-called artists have dedicated themselves to ornamenting the rich with images or quaint materialisations of this magical substance. From painting to fashion to jewelry, there are plenty of artists who simply use the aesthetics of money as a means to create uncritical and often tacky commodities that cater to the vanity of the wealthy, for the artist's own personal enrichment. Yet this half-strategy is, in and of itself, revealing.

As Marc Taylor (2011) notes, there is something qualitatively different about the new breed of collectors and artists that have emerged over the past twenty years. For Taylor, artist superstars like Takashi Murakami, Jeff Koons and Damien Hirst represent a paradigmatic break even from a previous generation of market-savvy artists whose figurehead might have been Andy Warhol. Under the new paradigm, artists not only coyly court the market as a means to further question and destabilise the modernist distinction between art and life, or to express a post-modernist scepticism with respect to the pretensions of the avant-garde (see Bürger 1984). Rather, financialised artists actively embrace their identity as a 'brand' without irony, introspection or reluctance, and also readily accept their role as the producers of speculative commodities within a speculative art market.

In his thoughtful response to Taylor's pessimistic and perhaps crypto-romantic castigation of these artists, Noah Horowitz (2011a), author of the fascinating book The Art of the Deal (2011b) and current managing director of the Armory Show art fair, confirms that, indeed, art today is deeply and profoundly effected by the financial power of an emerging sub-class of 'high net worth individuals' (HNWIs), whose crass and unapologetic approach to art as a luxury investment vehicle has even drawn the ire of art-world bogeyman/superstar collector Charles Saatchi (2011). But Horowitz also questions Taylor's desire to draw a sharp distinction between a financialised now and a seemingly more innocent then. Horowitz himself has been amongst the most cogent and insightful researchers in revealing the brave new world of 'art investment funds', and the curious economics of fine art financing, insurance, and auctions. Yet he rightly points out that Taylor's enthusiasm to make a clean break between the allegedly more savvy and critical gestures of Warhol and the supposedly unreflexive or blithe posturing of Hirst or Koons may be ill advised.

Whatever the case may be, the presence of the new class of HNWIs eager to collect and speculate on contemporary art cannot be denied, and nor can their impact on artistic production at the dawn of the twenty-first century (see Lindemann, 2007; Thompson, 2010; Thornton, 2008). It would appear that the veritable explosion of artworks that are either made of money or that feature or reflect on money cannot be separated from the growth of this lucrative market, and the simultaneous rise of international art fairs and branded multinational galleries. So the first half-strategy of art and money is simply a desire to cater to the market based on the conscious or unconscious recognition that, in an age when the bourgeoisie have lost almost all pretensions to refinement and taste - in the sense Bourdieu (1984) outlined - uncritical, almost brutalist art with or of money is highly saleable. What might have once seemed either avant-garde or ugly (possibly both) today sells with alacrity.

We might ask: what is it about the relationship of culture to economics today that would allow this critical work to find an audience amongst those whom it seeks to criticise? Is there a certain symbolic masochism at the heart of the financialised economy, wherein those who manage and benefit from money's postmodern empire throw their contorted souls into relief through their limited exposure to critique, like the proverbial CEO who hires the services of a dominatrix to exorcise his fraught, repressed soul, and so enable him to dominate his workers the following day? Or is there some degree of inoculation here, whereby the 'masters of the 
universe' accumulate critical art as a means to insulate themselves from that very critique, as if to immunise themselves with the tattered shred of a virus to train their proverbial immune systems against future exposure? Or perhaps this is simply the hubris of the victor: the elite collector ensnares the most critical artifacts of the art world as if to display the radicalism's head on the ramparts, or as if to keep some dangerous beast in a private zoo for the thrill of seeing it pace furiously behind the bars.

Perhaps, though I would offer another proposal too. Taylor is entirely correct in noting that the new breed of collectors eager to speculate on critical, contemporary art are, to a large extent, the beneficiaries and functionaries of the massive growth of the global financial apparatus. Those whose fortunes were made or are invested in the financial sector are by far the most prevalent among Art and Auction magazine's annual list of the world's most powerful art collectors. I would suggest that, in addition to the explanations listed above, we might also consider that something about contemporary art appeals to and reflects the 'soul' of financial practice. Unlike the business of managing workers and the production of material commodities, profiting in the financial realm is almost exclusively (at least for those at the very top) about navigating an immaterial world of relationships, probabilities, conjectures, and opportunities, or what I would call 'ætherwork'. Numerous scholars have observed that financial markets are effectively and essentially spheres of representation where real-world wealth is translated into the abstractions of derivative contracts, securitised and collateralised assets, and other flights of financial fancy (see Haiven, 2014). The degree to which these financial assets lose their connection to underlying wealth is a matter of debate, but suffice it to say that there is a great deal of merit in the observation that, from at least a certain perspective, financial work is cultural (see Appadurai, 2012). It is about convincing others that one's immaterial, abstract assets have value, that one's representations of wealth are credible (Marazzi, 2010). Perhaps the new financialised elite's seemingly voracious and omnivorous appetite for contemporary, critical art is based on a hunger for artefacts whose production resonates with their own experience and socio-economic conditions. After all, ours is a moment of post-modern scepticism towards any essentialist claims to art's value, when the practice of art itself has been thoroughly 'dematerialised', and when, as Boris Groys (2011) points out, critical art can be defined (at least in part) by the way it calls attention to its own process of transforming objects/spaces/practices into art. In other words, contemporary, critical art creates itself by somehow alerting us to its own production as art. It is art to the extent it gives itself value as art, to the extent it earns our credulity. Like a financial asset, contemporary, critical art gains its legitimacy and value as a gesture within a field of other similar gestures, and in ways that, ultimately, rely not on any objective criteria but on their capacity to achieve (at least temporary) credibility and believability within a specific symbolic and material eocnomy.

Speculation aside, the all-too-intimate connection between contemporary, critical art and the financial elite has been charted by writer and performance and installation artist Andrea Fraser (2012). A central figure in the development of practices of 'institutional critique', Fraser has written uncompromising critiques of the way contemporary, critical art has been folded into the domain of financial oligarchs. While the financial sector's support for contemporary, critical art is not new - we can trace it back at least to the mid-twentieth century when financial elites began to stack the boards of major contemporary art museums, notably New York's MOMA (Haacke, 1984; Saunders, 2000) - Fraser sees today's contemporary art world as highly disingenuous in its claims to authentic criticism of economic and political power, while all too comfortably (or with performative discomfort) deriving its own economic basis from the financial world, whether directly (in terms of sales of contemporary art to the financial 
elite) or indirectly (in terms of the financing of museums and foundations, funded by the financial elite).

\section{Strategy 1: Revelation}

In light of all this, the first critical strategy is a relatively naked attempt to use art's particular gravitas to comment on money's social and political power. If art, somehow, has - at least in myth, if not in fact - survived the neoliberal subordination of all spheres of social value to money's measure, perhaps art can mobilise that tenuous relative autonomy to reveal and expose money's authority that is otherwise insidiously normalised. Here I'll take two examples.

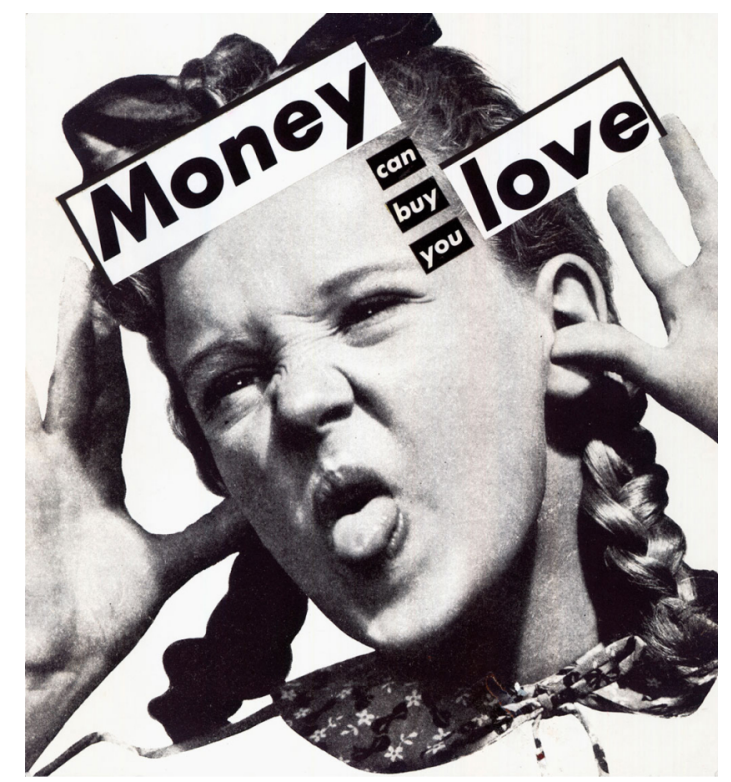

Figure 1. Barbara Kruger, Untitled (Money can buy you love), 1985. Collage. Courtesy of Sprüth Magers, Berlin and London.

Barbara Kruger has used her iconic and idiosyncratic style - one that developed from her background in print advertising design - to provide a poetic but relatively direct and didactic revelation of money's social power. Her work on money and economics alone has been compiled in a recent collection (2005), and has ranged from the blunt (for instance, her 2011 work Untitled: Money money money) to the slightly less blunt (the infamous 1987 Untitled: I shop therefore I am, which would become a hit marketing gimmick when silkscreened on totes for sale at gallery and museum shops). Indeed, over her forty-year career, Kruger has found an ever broader and more appreciative audience for this work. While once the mainstream art world saw Kruger's work as unsightly and pedantic aesthetic activism, today, ironically (or perhaps fittingly?) it hangs in many world-class museums and the homes of wealthy collectors. In a successful attempt to reveal money's social and cultural power through art, her art itself has become part of the economic circuit of money.

Another example of this first strategy is Blu, the Italian street artist, whose phenomenal murals have appeared around the world. Emerging from a radical Marxist milieu of Bologna (notable as a hub of the radical and militant Autonomia movement of the 1970s and '80s), Blu's work dramatises money's power to transform human agency and possibility, often mobilising natural themes to contrast the utterly unnatural or supernatural power of money over our lives and our world. This symbolism is magnified by a brilliant integration of the 
particularities of local public surfaces, and a keen but subtle attention to political-economic circumstances.

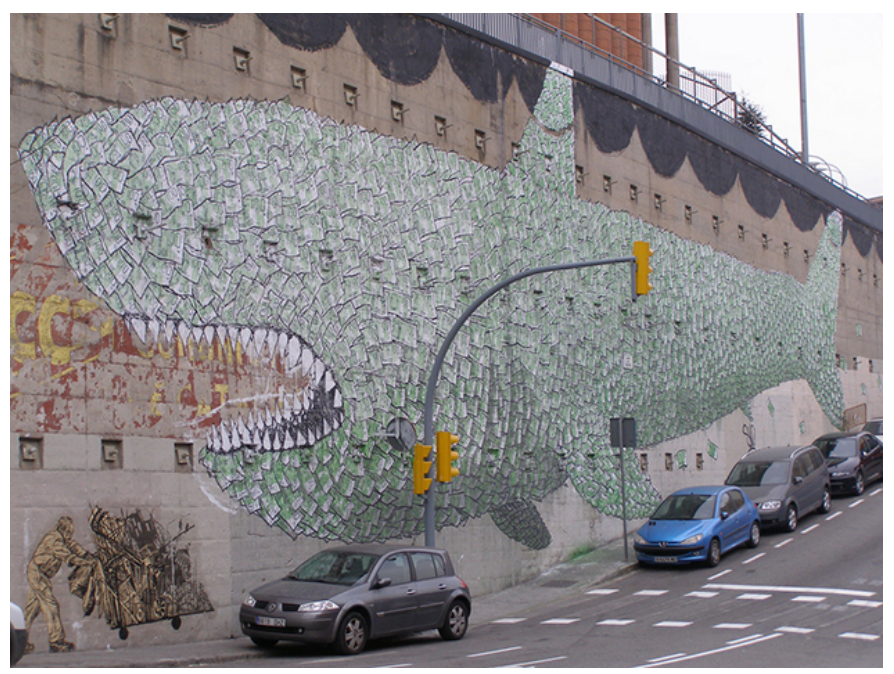

Figure 2. Blu, Money shark, 2010.

For instance, in a well-known piece 2010 piece, Blu covered a tapering wall in Barcelona in the image of a massive shark composed of dollar bills - a grim commentary on the paroxysms of austerity forced on Spain as a result of the global financial meltdown (Figure 2). In another 2010 piece, Blu created a mural on the side of a satellite location of the Museum of Contemporary Art in Los Angeles depicting wooden coffins draped in American dollar bills in a fashion reminiscent of the pageantry, ritual and propaganda of military funerals (Figure 3). Citing the potential offence the mural might cause to visitors to a near-by war memorial, the museum had the piece whitewashed within 24 hours.

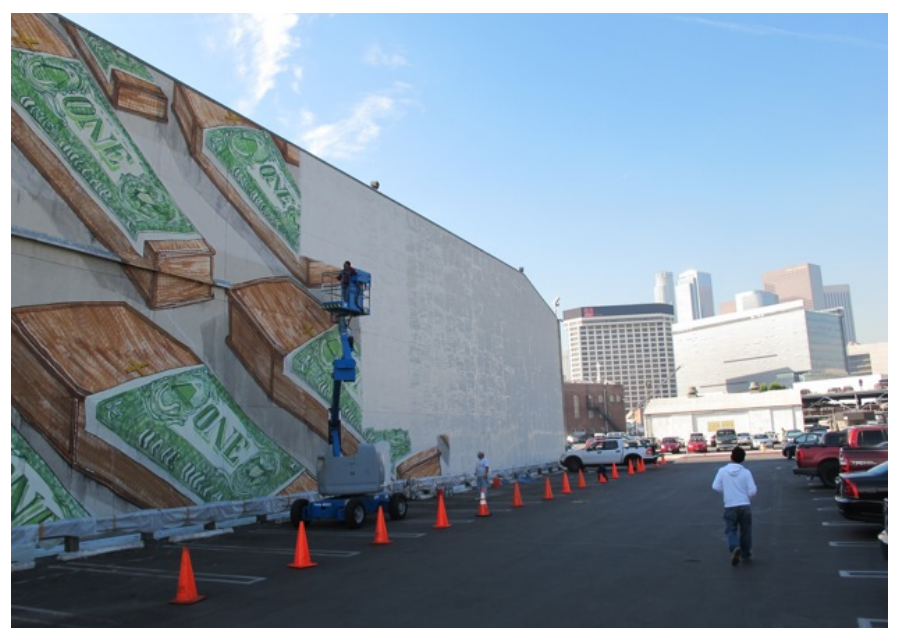

Figure 3. Workers whitewash a mural by the Italian street artist Blu at the Museum of Contemporary Art in Los Angelis, 9 December 2010. Photograph (C) Casey Caplow. Courtesy of good.is (http://www.good.is/)

Both Kruger and Blu's work have proven powerful and transformative. Their direct and unflinching critique of money's power, as well as their attention to its ironies and influences, have elevated these artists above their contemporaries who either ignore money entirely in 
their allegedly 'political' work, or who engage with money on the level of esoteric abstraction and self-indulgent cleverness. In an art market hungry for the performance of subtlety, nuance, complexification and the flavour of the savant, art that unapologetically engages power is rare indeed. Yet this first strategy remains largely within the romantic and modern idiom, even in spite of some more postmodern aesthetic elements. It posits the artist as the autonomous creative subject, revealing the truth of the world. It takes for granted that the representative power of the artist him or herself remains untainted or uncompromised. It leaves intact the mythology that art ('real' art) obtains a sacrosanct location of critique because it obeys a non-monetary set of values. And in this it perhaps does a disservice to the fraught and conflicted conditions that preoccupy the field today.

\section{Strategy 2: Reflexivity}

A second strategy, by contrast, seeks to show that art is not only sullied by but also complicit in money's terrible power. Work in this idiom attempts to reveal the deeper intersections of art and money, either in the historical or the contemporary frame. Unlike the first strategy, whose earnest interventions in some sense rely on the myth that ('real') art's guiding values are antithetical or at least resistant to market domination, this second strategy places such a mythology squarely within its sights. The politics here are largely deconstructive and, for that reason, court a sense of irony. As such, this strategy has at least two angles, one that I find laudatory, the other I find despicable.

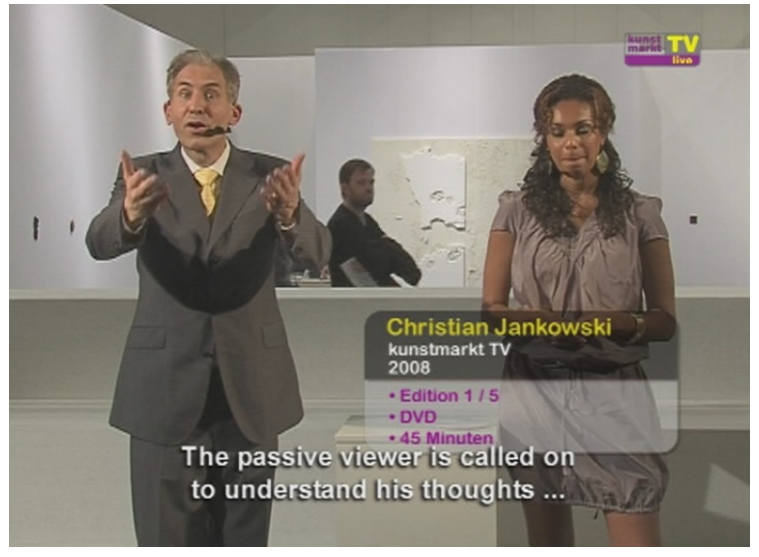

Figure 4. Christian Jankowski, Kunstmarkt TV, 2008. Video (still). Courtesy of the artist.

On the laudatory side, we have the work of artists like Christian Jankowski, whose 2008 video/installation Kunstmarkt TV depicts art for sale on the equivalent of the home-shopping network (Figure 4). The art collective SuttonBeresCuller's 2009 sculpture Distribution of wealth is a stack of one-hundred $\$ 1$ bills, sliced vertically into segments that correspond to the percentage of the work's sale price taken by the gallery, the dealer, and the artists themselves (Figure 5). These works inherit the legacy of earlier conceptual and political artists like Marcel Duchamp, who, in 1919, paid his dentist with a hand-drawn cheque from 'The Teeth's Loan \& Trust Company Consolidated of New York', or Joseph Beuys, who famously scrawled 'Kunst=Kapital' (Art=Capital) on Deutschmark notes and passed them back into circulation. Perhaps most notorious is the work of J.S.G. Boggs, the American artist who has made a well-publicised thirty-year career out of hand-drawing banknotes and, candidly, attempting to use them to pay for goods and services, inviting store clerks, waiters and others 
to enter with him into a self-conscious performative deliberation on the value of money and art (see Weschler, 1999).

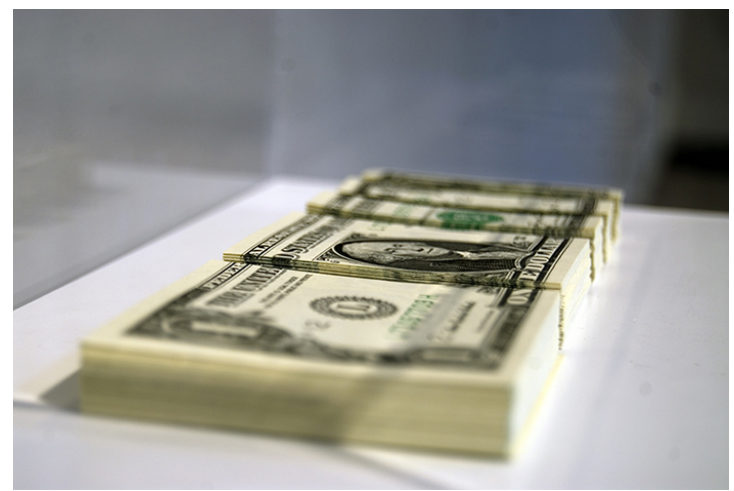

Figure 5. SuttonBeresCuller, Distribution of wealth, 2009. Installation. Courtesy of the artists.

Likewise, Brooklyn-based William Powhida uses large-scale pencil diagrams to illustrate the way power and money influence the art world (Figure 10). His works are unapologetically literal, with a disarmingly sorrowful candour. They are aimed, in part, at puncturing the overinflated myth that the realm of contemporary art is based on the noble and unassailable virtues of aesthetic value alone. The cartoonish and diagrammatic quality of this work resonates with a sort of lackadaisical Dadaism, a 'fuck you' to an art world that the artist knows no longer flinches at profanity. This is art with revolutionary implications (at least within the art world), yet made without any hope of a revolution. Do the responses that this work elicits rise above the mirthless chuckle of the alleged creative class? Does this work circulate like an interoffice memo in the art world, making fun of the boss (money), who of course couldn't care less what we think of him?

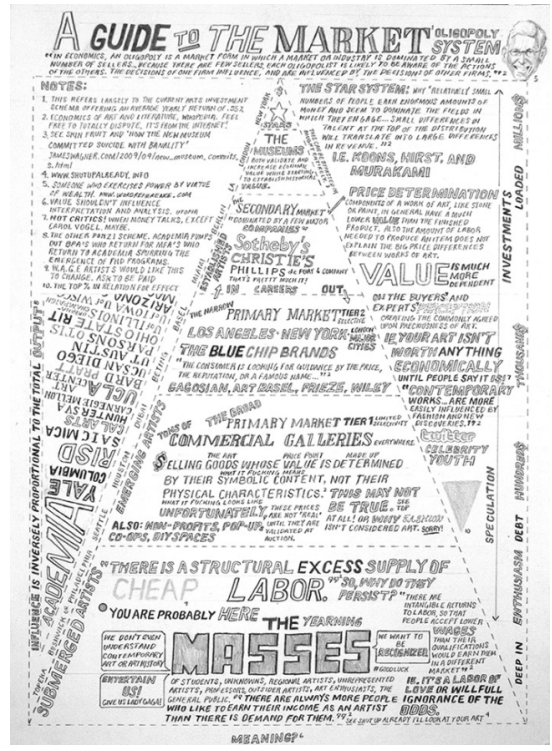

Figure 6. William Powhida, A guide to the market oligopoly system, 2010. Graphite on paper. Courtesy of the artist.

I believe this work is important and critical, in part because it speaks so acutely to the means and conditions of artistic production itself. As Angela McRobbie (2001; 2011) and 
many others have pointed out, the artist (or at least an idealised simulacrum of the artist) is held up today as the avatar of successful precarity, a figure who eschews any desire for stability, dependency, or conformity, and dedicates themselves body-and-soul to navigating the new paradigm of precarity, defined by multiple part-time contracts, a prestige-based job market, and the idiom of the passionate entrepreneur (see Holmes, 2007; Raunig, 2013). While the hyperbole surrounding the 'creative economy' may ring hollow, the ideal of the artist remains a paradigmatic figure, a false idol in an economy of self-sacrifice. In this context, Powhida's work, which deconstructs this mythology, is more than simply self-indulgent irony and morose navel-gazing. It seeks to destabilise the mythology of meritocracy, freedom, egalitarianism, creativity and individual fulfillment central not only to the exploitation of labour in the art economy, but also to the broader economy at large.

But this second strategy has its more despicable side as well, which, if we are to believe Taylor (2011) finds its origins in the work of Andy Warhol and its ultimate apotheosis in the work of Damien Hirst. This is a sort of art that candidly and unapologetically admits the influence of money and, indeed, embrace's the market's influence as not only natural but also right and good.

While Warhol's work might have been generative and important in its performative juxtaposition of money and art (Warhol famously stated "Being good in business is the most fascinating kind of art. Making money is art and working is art and good business is the best art'), his successors (seemingly an endless parade of art-world bad-boys) largely capitalise on the perennial surprise and delight this juxtaposition somehow still elicits. By the turn of the millennium, it is safe to say that Warhol's cool irony and post-innocent auteurism had become the baseline around which a scatterplot of branded artist-identities could be mapped. We can note the role that money plays in the work of the Young British Artists. There is Tracey Emin, both inheriting and commercialising the history of feminist art, desperately pulling money towards her crotch in her 2000 piece I've got it all. There are Jake and Dinos Chapman, doodling on money as a toothless 'intervention' at the 2007 Frieze Art Fair. And there is Damien Hirst, partnering with his friends in hedge funds to create a diamond-studded skull, the most expensive art object in human history, a gesture more worthy of the Guinness Book of World Records than the Museum of Modern Art (though perhaps revealing the deep affinity between the two venues).

All these works and the rest of their ilk self-consciously and blithely reveal art's dirty little secret: the incredible power of the market and of money, and the 'big lie' of art's autonomy. As all forms of power and influence become subordinated to money in a financialising, neoliberal economy, this work functions not only to reveal but also to revel in the sad truth that the 'relatively autonomy' from capital that art might once have enjoyed (and which gave the avantgarde's of the past their hope) is now defunct. Yet now that the revelation of this baleful fact is widely accepted, what is the profit in it? For artists like Powhida, such a project is part of a broader search for alternatives and for new forms of cooperation and collectivity. For artists like Hirst, Murakami, Koons, and others, it is about offering up irony, cleverness, sensation, and a whiff of brimstone in the form of highly priced vanity items for the financial class.

\section{An aside on mediation}

Whither art then? If the revelation of money's influence is too didactic, and the admission of art's complicity too cynical and mercenary, then how else can and should artists address money, the most powerful force of this or any age? A force so ubiquitous and intimate that we, each of us, now, today, wear it like a hidden badge or charm upon our persons? One which so 
preoccupies our individual and collective imaginations that we can quite literally not envision a world without it? Of course artists cannot avoid this theme.

The third and final strategy, then, is something more subtle, but also potentially quite radical. It is art that draws specific attention to the deep affinity between art and money as forms of mediation. For Jameson and other Marxist cultural critics, mediation is a complicated term. Capitalism is a system of material relationships whose ultimate horizon is its own replication. But history has shown us that this system is extremely mutable. Sometimes it develops complex systems of dynamic equilibrium, like Keynesianism, in order to placate (some) workers and regulate (some) markets. Other times it throws itself open to (seemingly) unfettered (allegedly) free markets. Other times still it descends into fascism and authoritarianism to protect ruling class interests (see Harvey, 2006). Constantly transforming in response to internal crises and external challenges, capitalism is never simply a pure system of accumulation. Rather, within its operations it develops, out of crisis-prone necessity, all manner of 'mediations': institutions, social structures, systems of value, and processes that are somehow at once peripheral to capitalism's core logic yet vital to the system's reproduction.

Money, as a special form of mediation, is both incidental and circumstantial to capitalism's functioning, yet also absolutely essential to it. Capitalism is not simply the rule of money over all of life. Rather, it is the rule of capital, in whose service money exists. The concept of mediation allows us to understand the way capitalism creates structures and social institutions that are at once very real and largely imaginary. For instance, we might likewise imagine the institution of monogamous heterosexual marriage as a mediation. While it is not a central part of the economic logic of the capitalist system (it does not typically generate immediate surplus value), it remains essential to the system in the way it structures the division of labour (which creates the bourgeois family as a space to extract surplus reproductive labour from women), everyday economic and social realities, and, more generally, a cultural system based on individualism and normative notions of 'success'. Marriage is a real thing (like money) with consequences, but it is also an idea, a set of practices or performances, and a socially and culturally enforced norm. Capitalism could, theoretically, do without marriage, but marriage plays a key role in the reproduction of capitalism today and, so, can't simply be discounted as 'merely cultural'.

Art, too, then is a form of mediation. Above and beyond any pieties about the inherently creative dimension of the human soul (no doubt true), 'art' is a very particular social institution that arises under capitalism and, in various complicated and crisis-prone ways, ultimately exists to help reproduce that system. The history of the emergence of 'art' as a response to an early bourgeois demand for exclusive and prestige-granting objects of taste and distinction is, by now, well known (see Wolff, 1984). The career of 'art' as such, and knowledge about art, has largely been preoccupied with affording the ruling classes with tools or props for their reproduction, providing them a means to distinguish themselves from the working class by recourse to taste, and an arena of cultural and social engagement where relationships (both business and pleasure) might be formed to consolidate and reinforce power, privilege, and wealth (Bourdieu, 1984). Art today, at least the art that circulates in the upper echelons of the 'art world', still largely fulfills this role (see Velthius, 2007). It is a form of mediation that helps ameliorate (or at least defer) a central crisis in capitalism: the ruling class must both compete and cooperate in order to make the system run. In addition, art today provides a variety of other 'services' to capital. As mentioned earlier, it has become the illusory North Star of freedom, fulfillment, and individualism on which increasingly all workers are expected to fix their gaze; it can offer an 'alternative asset class' investment to shore up other aspects of an 
investors portfolio (Thompson, 2011); donations and service to art in the public interest (museums, galleries, etc.) creates the illusion that the financialised elite actually care about the fate of culture and humanity. These are but a few examples. Suffice to say that art, as a form of mediation, plays a variety of important roles in the reproduction of capitalist social and economic relations.

Yet the other dimension of the theory of mediation is that, within various mediations, the seeds of crisis and of resistance are borne. In the case of art, it's utility to capitalist reproduction has afforded it a strange dimension of relative autonomy, although one quickly disappearing. Because art's capitalist functionality has relied on it being imbued with a mythology of freedom, creativity, individuality and obedience to a non-economic logic of value, these qualities have opened a space for critical and potentially radical critique. This, at least, was the hope of the avant-garde, who found in art all those values and qualities otherwise obliterated and subjugated under capitalism. Likewise, Herbert Marcuse (1978) was, in his final work, to make a passionate argument for the way art and beauty could puncture the otherwise hermetically-sealed cultural idiom of capitalism that reduced all (other) things to their instrumentalities.

Yet it would appear that this sliver of critical, dialectical distance has, in the past decades, been recuperated and reclaimed by capital. With the enfolding of what I have here termed 'strategy two' into the mainstream aesthetic regime of capital, with the hunger of the financialised bourgeoisie for critical, contemporary art, where might we find the radical potentials of art at large, and, more specifically, money-art?

To gain some purchase on this question it is worth revisiting the Marxian distinction between exchange and use value. A common misreading of Marx produces the idea that capitalism is simply about the subordination of use value to exchange value, the domination of everything by its price. This is partially true, but it is complicated by a few factors. One is that, in addition to raw prices, capitalism depends on certain objects or processes still having a use value. A loaf of bread's value in capitalism isn't just the price it earns on the market, it is also its utility in reproducing workers' bodies, workers, and therefore abstract labour power, surplus value, and ultimately capital. Occasionally, the contradictions and complexities of the system reach such a degree that the exchange values totally overshadows use values, such as when a market crisis causes massive inflation, meaning the worker can't afford to eat. But in less dire times all commodities under capitalism are, in actuality, circulating in many different economies of value at the same time, both use and exchange. This is not only the source of conflict and crisis, such as various crises of over-production or under-consumption; it is also the source of resistance, like a bread riot (see Cleaver, 2000).

The second and derivative point here is that, in a world of mediations, we never have unadulterated access to the use value of anything. Our sense of a thing's usefulness and its 'true' value is, under capitalism, always mediated. That is, even though we might 'use' a commodity in ways unrelated to the market (like eating a loaf of bread), we can never experience its 'pure' use value because that sense of value is always mediated by its many other functions (not only its exchange value).

Hence, something like art, even to the extent it is commodified, and even to the extent it is increasingly subordinate to the raw calculus of the market, remains 'useful' in a variety of (contradictory) ways. We have already seen the various 'uses' for art in the reproduction of the ruling class, especially the uses of today's critical, contemporary art in the reproduction of a highly financialised ruling class. We can also point to the more hopeful and uplifting 'use values' of art for the rest of us: its capacity to break us out of our habitual modes of thinking, feeling and engagement; the odd little crack of freedom it offers in an otherwise commodified 
and instrumentalised world, through which an feeble beam of light might shine; its ability to broaden what Jacques Ranciére (2007) calls the 'distribution of the sensible' - to challenge our preconceived or habitual notions of who and what 'belongs' (in the gallery, in the nation, in the heart). But the key lesson from Marx is that none of these values is ever pure. The value of a Warhol can be and usually is all of these layers of value together in a palimpsest: its market value at auction; its value in art history; its value as a domesticated object in the collection of a hedge fund manager; and its value as a critical work of art that opens new horizons of thought and action.

Money is a special case commodity, one where, at least ideally, the object's only use value is its ability to represent exchange value. As we somehow never tire of hearing, money is, otherwise, useless: you can't eat it, you can't have a relationship with it, it's only use is to facilitate and expedite exchange. It functions to the extent it becomes the measure of value for all other things. The neoliberal, financialised moment of capitalism is one when, increasingly, all other spheres of life and value are in the process of being collapsed under money's measure. For this reason, Marx refused to understand money as simply a neutral tool, a means to achieve and negotiate other values, which was (and still is) the mainstream opinion among economists (see Nelson, 1999). Under capitalism, money does not facilitate use values, it subordinates them to the interests of capitalist reproduction (Caffentzis, 2013). It is unique among commodities in this sense. And because of it's universalised power, money also becomes a sort of false reflection of the capitalist totality discussed earlier. To the extent that money becomes our key means of negotiating value in capitalist society, money comes to stand in for everything. Marx (1964: 165) was to famously write that "[t]he individual carries his social power, as well as his bond with society, in his pocket". What is important here, and key to Marx's concept of commodity fetishism, is the way money is a misrecognition of our own collective creative power. The totality in which we live is the product of 'our' constant, collaborative, creative labour, a labour that we fail to remember because our relationship to our fellow labourers is mediated by money (we are paid a wage for commodifying our time and creating commodities, with which we buy back commodities, the frozen fragments of our and others' labours).

Money in this sense consummates art's ideal: pure mimesis. To the extent we take money to be a real representation of value, to the extent we, without pause, accept its claims to represent the real world, we surrender our power to it. Of course, overcoming capitalism is not merely a matter of ceasing to believe in money's claims to value - it demands a fundamental transformation of the economic system and social relations. But it is to say, that, in money "society always pays itself in the counterfeit coin of its own dream", as Marcel Mauss famously put it (see Graeber, 2001). Money is the cruel, revanchist residue of our own estranged labour. Money is an incredibly powerful means by which we mediate our cooperation, and a means that transforms our cooperation towards its ends. It is mediation itself materialised, and so it appears as immediate, unmediated, perfect and mimetic. This is an appearance that is both held in place by and helps to reproduce daily life and economic circulation within a capitalist totality.

In contrast, as Groys (2011) and others point out, what defines contemporary art today is its tendency to call attention to its own processes of mediation, to conspicuously announce the conditions and procedures of its social production and to highlight the participation of audiences and institutions in these processes. And if this is the case, then contemporary art that mobilises money as theme or media is inherently borne of a friction that might spark the radical imagination. Both money and art, each in their own way, are necessary mediations of a capitalist totality. The success of the former depends on the obscuration of this fact. The 
success of the latter depends on revealing it. Yet in spite of that, both are are corrupted, impure, and largely unconscious means by which we come to terms with, negotiate, and contest the relations of socially cooperative labour. Perhaps the most promising and radical money-art, then, is that which sensitises us to our collective power, a power whose organisation and mediation we usually unthinkingly surrender to money. This would be art that allows us to remember what we are always in the process of forgetting: that the social world and all its mediations are the products and the producers of our social bonds.

\section{Strategy 3: Rendering labour visible}

In other words, both art and money are holographic shards of a greater totality. The nature of that totality is not simply the saturation of all social and cultural life with the dictates of capital; it is something deeper. The totality refers to that unimaginable, sublime aggregate of human cooperation and creativity that capital seeks to discipline, shape, harness, and transform. The third strategy of money-art, I argue, speaks (always in a partial, incomplete way) to this unimaginable, interconnected, inter-reliant whole, and to money's power over and emergence within it. But it also speaks to the creative and cooperative potential underneath, which is the source of all our hope and, perhaps, of all beauty, if we can still talk of such a thing. There exists a subversive ætherwork at the tectonic overlap of art and money in their historically contingent and politically potent manifestations.

I close with two examples. The first is Italian installation and conceptual artist Cesare Pietroiusti, whose work with money has been particularly thoughtful, playful, and profound. For instance, Pietroiusti routinely uses his artist's fee as a medium, creating work that is difficult or impossible to sell or value (Figure 7). In his 2008 Untitled (Three thousand US dollar bills to take away), an installation for the exhibition 'Art Price Value: Contemporary Art and the Market' at Centro de Cultura Contemporanea a Palazzo Strozzi in Florence, Pietroiusti conducted a series of experiments applying sulphuric acid to 3000 American $\$ 1$ and $\$ 5$ banknotes, then signed them and stamped the back with a note explaining that "each monetary transaction involving this artwork will invalidate the signature of its author and consequently transform it into a fake' (Figure 8).

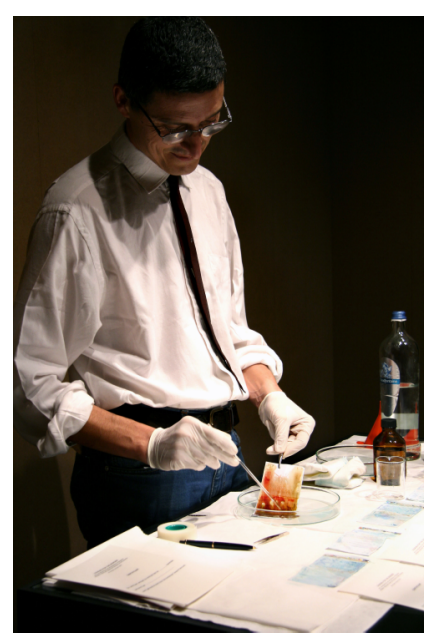

Figure 7. Cesare Pietroiusti. Image from an untitled 2007 performance in Bruxelle, in which the artist treated money with sulfuric acid. Photo by Martina Della Valle. Courtesy of the artist. 


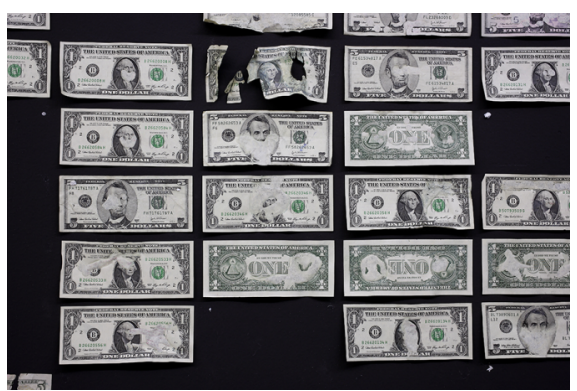

Figure 8. Cesare Pietroiusti, Untitled (Three thousand US dollars to take away), 2008. Detail from installation and performance. Photo by Serge Domingie. Courtesy of the artist.

The bills were hung on the wall of the gallery and visitors were encouraged to take them as souvenirs. Here Pietroiusti draws the audience into a speculative and actual set of relationships with money. This complex, multi-layered piece, which deconstructs the value of both art and money is not simply satisfied to reveal their contradictions and ironies, as per strategy two. Rather, Pietroiusti is mobilising art's peculiar location at the intersection of multiple forms of value to create a temporary space where, for a moment at least, we can pay attention to the work we are all always already doing to reproduce capitalist social relations, taking advantage of the friction generated between money and art's representational qualities and social roles.

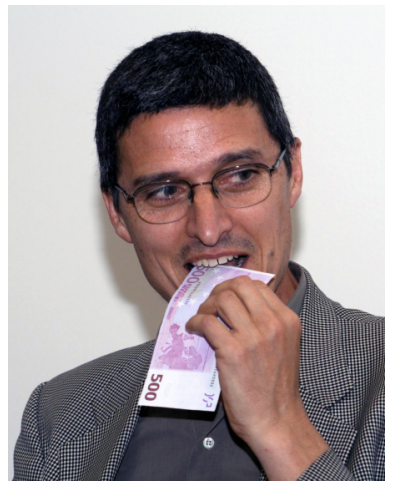

Figure 9a. Cesare Pietroiusti and Paul Griffiths, Eating money: An Auction, 2005-2007. Performance at the Ikon Gallery in Birmingham, UK. Photo by Caters News. Courtesy of the Ikon Gallery.

More illuminating still is his performance Eating money: An Auction (Figure 9a), which sees he and sometimes other artists host a gallery-based auction where the audience bids with paper money. The person offering the largest denomination gives it to the artist who promptly swallows it. After it passes through his system, the bill is cleaned, sanitised, framed and returned to the original investor (Figure 9b). Here, the artist digests the object and transforms its economic value into aesthetic value. Given Pietroiusti's reputation, we can imagine that the art-object-that-was-once-money has gained a new economic value in excess of the 'face value' of the paper money itself. Pietroiusti is not merely cynically calling attention to the intimate (scatological) relationship between art and money, as per strategy 2 - his somewhat cheeky performance also asks us to consider a deeper question: how do we create value together? How does shit become gold, and gold become shit? How is it that we bestow power on art and money? 


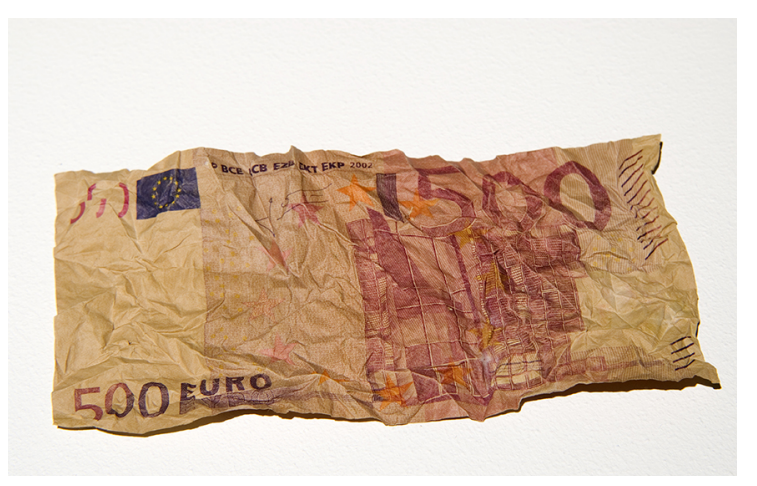

Figure 9b. Cesare Pietroiusti and Paul Griffiths, Eating Money: An Auction, 2005-2007. Performance at the Ikon Gallery in Birmingham, UK. Detail of one banknote after passage through the artist's body. Photo by Caters News. Courtesy of the Ikon Gallery.

In another piece, Money watching (Figure 10), Pietroiusti used the auspices of a storefront gallery in Bristol to open a 'money store'. Passersby were invited to 'purchase' a $£ 10$ or a $£ 20$-note in return for, respectively, 15 or 25 minutes worth of undivided attention. The 'customer' was to stare at the note, placed in a glass display case, for half the duration per side, after which it was given to them. Here, Pietroiusti transforms the art event into (or perhaps reveals the art event to be) a scene of almost meaningless commercial transaction. By harnessing the 'customer' or audience's useless, immaterial labour, they become complicit in a ritual for creating value. This potentially reveals the nature of both aesthetic and economic value, and the way this arbitrary nature is enforced and encoded through spaces and objects: the disciplinary space of the gallery which encloses the meaning of art; or the aesthetic form of money itself which, unlike any other object, so seamlessly convinces us of its value.

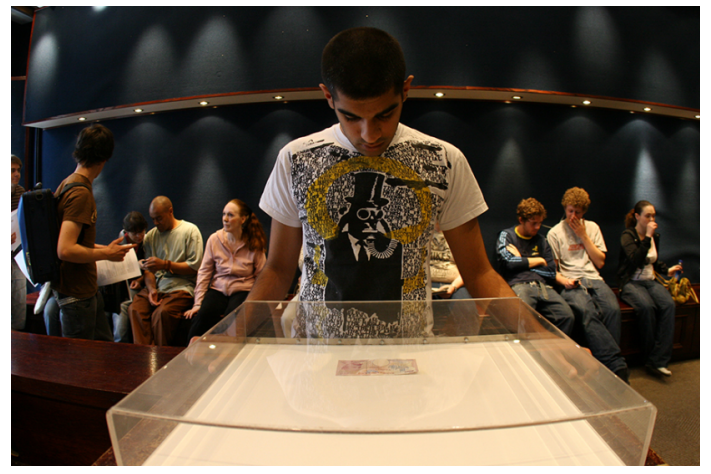

Figure 10. Cesar Pietroiusti, Money watching, 2007. Performance and social action at a Birmingham shop-front. Photo by Chris Keenan. Courtesy of Ikon Gallery and the artist.

Another artist well worth dwelling with is the Mexico City-based artist Máximo Gonzáles, who has been working with international bills as artistic media for almost a decade. Gonzáles joins hundreds (probably thousands) of other artists seduced by paper money's strange and terrible power and beauty, but he ranks among the most adept, both conceptually and technically speaking. 


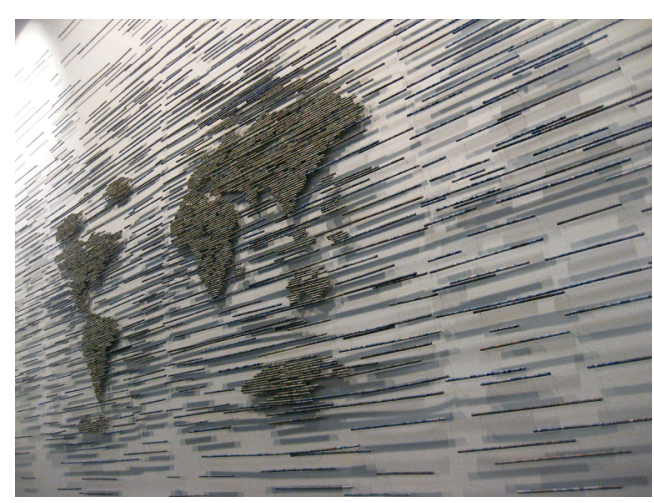

Figure 11a. Máximo Gonzáles, Numismagia, 2011. Side view. Out-of-circulation money, wooden sticks and pins. Courtesy of the artist.

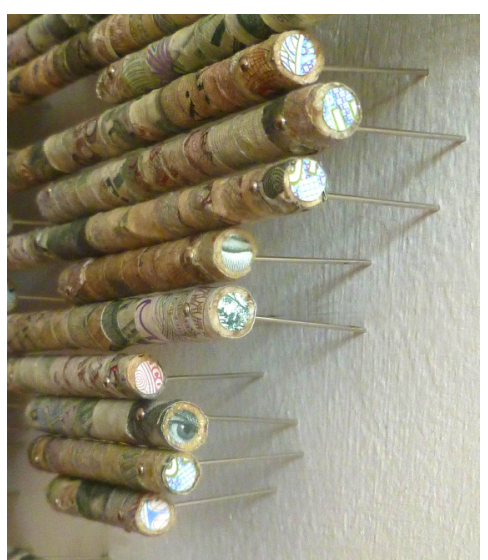

Figure 11b. Máximo Gonzáles, Numismagia, 2011. Detail. Out-of-circulation money, wooden sticks and pins. Courtesy of the artist.

His work evidences a great deal of care and creativity in exploring the formal qualities and potentials of paper money, and his work - which often takes the form of large-scale pieces or installations - is marked by a painstaking attention to detail which other money artists, fascinated as they are by the conceptual richness of working with money, all too typically forgo (Figure 11). Gonzáles has experimented with the textility or textuality of money, transforming bills into thread or yarn with which he has woven elegant tapestries, works which illuminate money's influence in and reliance on the warp and weft of human activity (Figure 12).

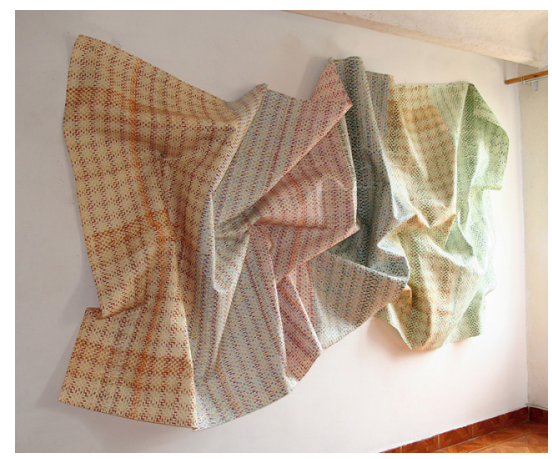

Figure 12. Máximo Gonzáles, Big magma CCCLXX-I, 2011. Installation view. Money and glue. Courtesy of the artist. 
In several recent pieces, Gonzáles has experimented with punching holes in and stitching together money, almost to the point of its total dematerialisation (Figures 13 and 14).

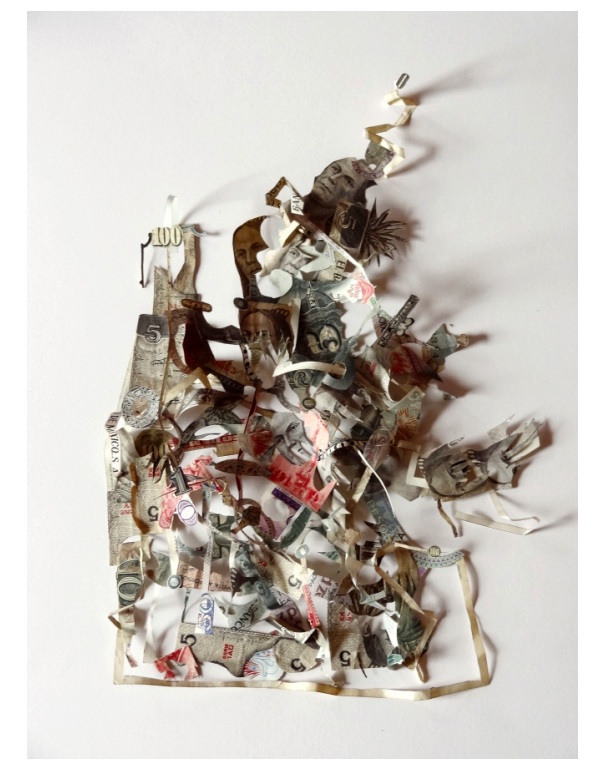

Figure 13. Máximo Gonzáles, Basura sin paisaje (Landfill without landscape), 2012. Detail. Out-ofcirculation money. Courtesy of the artist.

Visually echoing the decaying and decomposing garbage to be found in landfills all around the world, Gonzáles' work demands that we question what gives money value by all but destroying the object, leaving only enough for us to recognise its original form. There is something postapocalyptic and melancholic here, as if we are alien visitors observing the wreckage of capitalist totality and the destructive civilisation it has wrought upon the earth, as if this shredded, dirty, decomposed money is a twisted sacrament, a prayer shawl or cleric's robe stripped of its holy power, left to deconstruct itself in the absence of pious believers.

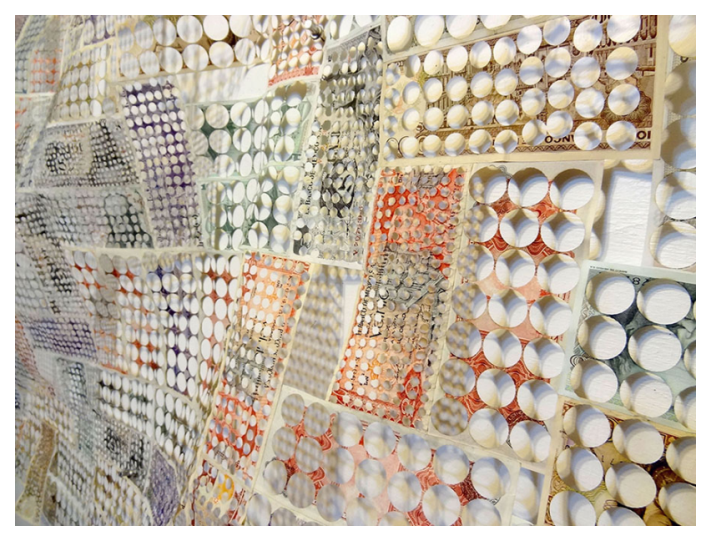

Figure 14. Máximo Gonzáles, La basura del mundo (The world's garbage), 2012. Detail. Out-ofcirculation money and pins. Courtesy of the artist.

Yet so too is there a sense of tender fragility. Unlike less subtle works, which simply seek to heavy-handedly reveal that paper money is 'worthless', these pieces seem to allow our disbelief to continue to be suspended, but by only a thread. Here, again, we might be able to move beyond a certain cynicism or pessimism and recognise that, for all the misery it causes, 
and for all the perversions of value it superintends, money is, in one sense, tremendously creative.

I do not mean this in the way that free market boosters celebrate the inherent creative power of capitalism, lauding the 'creative destruction' the system unleashes and that allegedly sweeps away inefficiency and drives innovation (see Haiven, 2014: 130-54). Instead, I am thinking of the constant, everyday creative work we are all doing all the time to reaffirm money's value. After all, if money is something of a public conspiracy to ascribe value to a useless thing, are we not all, on some level, guilty of an unchosen quotidian artistry, a certain daily work of belief and meaning making? Just as the twentieth century has taught us that the art object makes creative subjects of us all, requiring not only a creative genius as an originator but also active and reflexive audiences, so too might we recognise that money demands of us a creative labour we rarely, if ever, recognise as such. Nothing is more basic and banal than the getting and spending of money, but also nothing more profound, spiritual, and generative.

Of course to this we must add that this is not a creativity or artistry we freely chose. While money may indeed be a figment of our imaginations, it is not enough to simply cease to believe in its value for it to cease to control our lives. Money oversees a global division of creative labour, which systematically denies the vast majority of humanity the means and the opportunites to exercise their creativity in any meaningful way, or to have that creativity valued. At the same time as it is driven by an everyday creativity, money also stifles, constrains, parches and delimits our imaginations. Money, as Marx explained, causes us to fundamentally misrecognise the creativity we all exercise everyday in reproducing society and the capitalist economy that preys on it. And to this we might add that today's monetary order reproduces and is reproduced by horrific inequalities.

And yet perhaps in money-art these more profound realisations have a chance to emerge. Perhaps in their explicit failure to represent totality, in the way they call attention to both art and money's inherent limits, these works provide an avenue by which money's terrible power might, in fact, be challenged.

\section{References}

Anderson, P. (1998) The Origins of Postmodernity. New York: Verso.

Appadurai, A. (2012) The Spirit of Calculation. Cambridge Anthropology, 30(1): 3-17.

Berardi, F.B. (2012) Emancipation of the Sign: Poetry and Finance During the Twentieth Century. e-flux, 39(11).

Bourdieu, P. (1993) The Field of Cultural Production: Essays on Art and Literature. New York: Columbia University Press.

Bourdieu, P. (2005) The Social Structures of the Economy. Cambridge: Polity.

Bürger, P. (1984) Theory of the Avant-Garde. Minneapolis: University of Minnesota Press.

Caffentzis, G. (1989) Clipped Coins, Abused Words, and Civil Government: John Locke's Philosophy of Money. Brooklyn: Autonomedia.

Caffentzis, G. (2013) The Power of Money: Debt and Enclosure. In: In Letters of Blood and Fire: Work,

Machines, and the Crisis of Capitalism. Brooklyn: Autonomedia, 236-40.

Cleaver, H. (2000) Reading Capital Politically. San Francisco: AK Press.

Foucault, M. (1979) Discipline and Punish: The Birth of the Prison. New York: Vintage.

Fraser, A. (2012) There's No Place Like Home / L‘1\% C'est Moi. Continent, 2(3): 186-201.

Graeber, D. (2001) Toward and Anthropological Theory of Value: The False Coin of Our Own Dreams.

New York: Palgrave. 
Groys, B. (2011) Art and Money. e-Flux, 24(4).

Haacke, H. (1984) Museums, Managers of Consciousness + Art as Industry. Art in America, 72(2):

9-17.

Haiven, M. (2014) Cultures of Financialization: Fictitious Capital in Popular Culture and Everyday Life. Basingstoke: Palgrave Macmillan.

Harvey, D. (1990) The Condition of Postmodernity: An Enquiry into the Origins of Cultural Change. Oxford: Blackwell.

Holmes, B. (2007) The Speculative Performance: Art's Financial Futures. European Institute for Progressive Cultural Policies, January. Available at:

<http://eipcp.net/transversal/0507/holmes/en/>. Accessed 30 October 2012.

Horowitz, N. (2011a) Comment on 'Financialization of Art' (by Mark C. Taylor). Capitalism and Society, 6(2): 1-8.

Horowitz, N. (2011b) Art of the Deal: Contemporary Art in a Global Financial Market. Princeton:

Princeton University Press.

Jameson, F. (1981) The Political Unconscious. Ithaca: Cornell University Press.

Jameson, F. (1990) Cognitive Mapping. In: Nelson, C. and Grossberg, L. (eds.) Marxism and the Interpretation of Culture. Chicago: University of Illinois Press, 347-60.

Jameson, F. (1991) Postmodernism, Or the Cultural Logic of Late Capitalism. Durham: Duke University Press.

Jameson, F. (2011) Representing Capital: A Reading of Volume One. New York: Verso.

Kruger, B. and Phillips, L. (2005) Money Talks. New York: Skarstedt Fine Art.

La Berge, L.C. (2013) The Rules of Abstraction: Methods and Discourses of Finance. Radical History Review, 118: 93-112.

Lapavitsas, C. (1999) Political Economy of Money and Finance. Basingstoke: Macmillan.

Lindemann, A. (2006) Collecting Contemporary Art. Cologne: Taschen.

LiPuma, E. and Lee, B. (2004) Financial Derivatives and the Globalization of Risk. Durham: Duke University Press.

Mackenzie, D. (2006) An Engine, Not a Camera: How Financial Models Shape Markets. Cambridge: MIT Press.

Marazzi, C. (2008) Capital and Language: From the New Economy to the War Economy. New York: Semiotext(e).

Marazzi, C. (2010) The Violence of Financial Capitalism. Los Angeles: Semiotext(e).

Marcuse, H. (1978) The Aesthetic Dimension: Towards a Critique of Marxist Aesthetics. Boston: Beacon.

Marx, K. (1964) The Economic and Philosophical Manuscripts of 1844. New York: International. McMurtry, J. (2002) Value Wars: The Global Market Versus the Life Economy. London: Pluto Press.

McRobbie, A. (2001) 'Everyone is Creative': Artists as New Economy Pioneers? Open Democracy, 29 August. Available at: <http://www.opendemocracy.net/node/652/>. Accessed 16 October 2012.

McRobbie, A. (2011) The Los Angelesation of London: Three Short Waves of Young People's MicroEconomies of Culture and Creativity in the UK. In: Raunig, G., Ray, G., and Wiggenig, U. (eds.) Critique of Creativity. London: Mayfly, 119-32.

Nelson, A. (1999) Marx's Concept of Money: The God of Commodities. New York: Routledge.

North, P. (2007) The Politics of Monetary Contestation. In: Money and Liberation: The Micropolitics of Alternative Currency Movements. Minneapolis: University of Minnesota Press, 19-40.

Patel, R. (2007) Stuffed and Starved: Markets, Power and the Hidden Battle for the World's Food System. Toronto: Harper Collins.

Rancière, J. (2007) The Future of the Image. New York: Verso.

Raunig, G. (2013) Factories of Knowledge, Industries of Creativity. Los Angeles: Semiotext(e). 
Saatchi, C. (2011) The Hideousness of the Art World. The Guardian, 2 December. Available at: <http://www.theguardian.com/commentisfree/2011/dec/02/saatchi-hideousness-art-world/> Accessed 5 October 2012.

Saunders, F. (2000) The Cultural Cold War: The CIA and the World of Arts and Letters. New York: New Press.

Shell, M. (1994) Art and Money. Chicago: University of Chicago Press.

Siegel, K. and Mattick, P. (2004) Art Works: Money. London: Thames and Hudson.

Taylor, M.C. (2011) Financialization of Art. Capitalism and Society, 6(2): 1-19.

Thompson, D. (2010) The \$12 Million Stuffed Shark: The Curious Economics of Contemporary Art. London: Palgrave Macmillan.

Thornton, S. (2008) Seven Days in the Art World. New York: W.W. Norton.

Velthuis, O. (2007) Talking Prices: Symbolic Meanings of Prices on the Market for Contemporary Art. Princeton: Princeton University Press.

Weschler, L. (1999) Boggs: A Comedy of Values. Chicago: University of Chicago Press.

Wolff, J. (1984) The Social Production of Art. New York: New York University Press. 